\title{
BUKU IPA DILENGKAPI DENGAN TEKNOLOGI AUGMENTED REALITY: MELATIH KEMAMPUAN PEMBELAJARAN SAINTIFIK SISWA SMP KELAS VIII SEMESTER GANJIL
}

\author{
A. Handjoko Permana ${ }^{\text {a) }}$, Fauzi Bakrib), Wahyunic ${ }^{\text {() }}$ \\ Prodi Pendidikan Fisika, FMIPA Universitas Negeri Jakarta, Gedung Hasyim Ashari lantai 5 Kampus A UNJ, \\ Jl. Rawamangun Muka Jakarta 13220

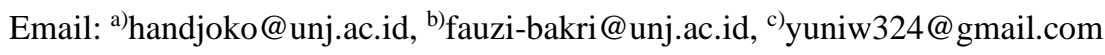

\begin{abstract}
Abstrak
Pembelajaran abad 21 menekankan peserta didik untuk melatih pembelajaran saintifik. Tujuan penelitian ini adalah untuk menghasilkan Buku IPA SMP yang dilengkapi Augmented Reality untuk melatih pembelajaran saintifik pada siswa SMP kelas VIII semester Ganjil. Metode yang digunakan adalah metode penelitian dan pengembangan (Research and Development) dengan model pendekatan sistem yang dirancang oleh Walter Dick dan Lou Carey. Buku IPA dilengkapi Augmented Reality ini diharapkan dapat meningkatkan kemampuan memecahkan masalah, berpikir ilmiah, menganalisis, mengklasifikasi, dan menyimpulkan keputusan. Instrument validasi yang digunakan berupa kuesioner skala likert dengan responden para ahli (materi dan media) dan pengguna (guru dan siswa).
\end{abstract}

Kata-kata kunci: Research and Development, Buku IPA, SMP, Augmented Reality, Pembelajaran Saintifik

\begin{abstract}
21st century learning emphasizes students to train scientific learning. The purpose of this study was to produce a Junior High School Science Book equipped with Augmented Reality to train scientific learning in Odd semester VIII junior high school students. The method used is the research and development method with a system approach model designed by Walter Dick and Lou Carey. This science book equipped with Augmented Reality is expected to improve problem solving skills, think scientifically, analyze, classify, and conclude decisions. The validation instrument used was a Likert scale questionnaire with respondents from experts (material and media) and users (teachers and students).
\end{abstract}

Keywords: Research and Development, Science, Middle School, Augmented Reality, Scientific Learning.

\section{PENDAHULUAN}

Konteks pembelajaran abad 21 terutama pada kurikulum 2013 menekankan pada proses pembelajaran dengan pendekatan saintifik. Pembelajaran pendekatan saintifik adalah pembelajaran 
yang dirancang secara prosedur sesuai dengan langkah-langkah umum kegiatan ilmiah. Proses pembelajaran saintifik mengimplementasikan kegiatan mengamati, menanya, menalar, menegosiasi, dan mengkomunikasi [1]. Penerapan kurikulum 2013 yang berlaku saat ini adalah ketersediaan perangkat pembelajaran yang layak dan relevan. Pada proses pembelajaran, tenaga pendidik harus menyesuaikan segala kegiatan pembelajarannya dengan Kurikulum tersebut, khususnya dalam penyusunan perangkat pembelajaran yang merupakan salah satu alat penunjang keberhasilan pembelajaran. Perencanan proses pembelajaran mengharuskan pendidik pada satuan pendidikan untuk mampu mengembangkan perencanaan pembelajaran [2].

Salah satu perencanaan perangkat pembelajaran yang dibutuhkan adalah bahan ajar, yang tentunya mengacu pada kurikulum tersebut. Namun, saat ini ketersediaan bahan ajar yang sesuai dengan kurikulum 2013 dinilai sangat kurang. Menurut hasil observasi yang dilakukan pada tanggal 13 Februari 2019 melalui google form oleh siswa-siswi sekolah menengah pertama (SMP) di Bekasi dan Jakarta bahwa dalam pernyataannya didapatkan 53,5\% siswa-siswi kurang menarik pada tampilan buku teks SMP.

Maka dari itu, agar tuntutan tersebut dapat dilaksanakan sebagai bagian dari implementasi kurikulum 2013, maka perlu melibatkan penggunaan kemajuan Teknologi Informasi dan Komunikasi secara tepat, berkelanjutan, dan terjangkau sesuai dengan kemajuan Teknologi Informasi dan Komunikasi saat ini. Teknologi yang dapat menggabungkan objek nyata dan objek virtual dengan lingkungan nyata yang dapat terintegrasi antarbenda dalam tiga dimensi, yaitu benda maya terintegrasi dalam dunia nyata [3-4]. Menerapkan inovasi teknologi Augmented Reality dalam pembelajaran, akan tercipta suatu suasana belajar yang efektif dan memberikan gambaran tentang lingkungan dunia nyata dalam sistem pembelajaran yang berbasis komputer.

Augmented reality sangat berpotensi dalam menarik, menginspirasi, dan memotivasi siswa, untuk mengeksplorasi dan melakukan pengontrolan dari berbagai prespektif yang berbeda, yang sebelumnya tidak menjadi bahan pertimbangan dalam dunia pendidikan. Beberapa penelitian mengemukakan bahwa, AR dalam bentuk buku dapat memungkinkan pelajar untuk berinteraksi dan tertarik dengan konten buku, sehingga dapat menolong pelajar yang memiliki masalah untuk mengerti materi pembelajaran text based yang digunakan dalam dunia pendidikan saat ini [5-8]. Potensi AR ini dikarenakan keunggulan AR yang dapat menjelaskan konsep melalui simulasi 3D [910], AR sebagai media untuk mendukung pembelajaran dengan high-order thinking skills [11-12], dapat mendukung kegiatan praktikum di laboratorium [13], atau bahkan menjelaskan fenomena fisis yang sulit dikondisikan dalam dunia nyata [14].

Atas keuanggulan-keunggulan AR, maka media dengan tambahan teknologi AR diyakini dapat mendukung pembelajaran saintifik siswa, mengingat kemampuan saintifik sangat berperan dalam capaian pembelajaran siswa [15.Berdasarkan uraian tersebut, maka perlu dilakukan pengembangan buku pelajaran berbasis AR yang berjudul "Pengembangan Buku IPA SMP Dilengkapi Augmented Reality Untuk Bahan Pembelajaran Saintifik Di Kelas VIII Semester Ganjil" untuk pemanfaatan Augmented reality (AR) dalam Buku IPA yang mampu mengharapkan media dua dimensi menjadi 3 Dimensi.

\section{METODOLOGI}

Metode penelitian yang digunakan pada penelitian ini adalah metode penelitian dan pengembangan (Research and Development) yaitu dengan mengembangkan suatu produk dan menguji kefektifan produk tersebut. Menurut Brog dan Gall model penelitian dan pengembangan pendidikan (Educational Research and Development) yang dapat digunakan adalah model pendekatan sistem yang dirancang oleh Walter Dick dan Lou Carey. Model Dick \& Carey dimodifikasi oleh Atwi Suparman dalam buku desain instruksional modern menjadi model pengembangan instruksional (MPI).

Penelitian ini bertujuan untuk mengembangkan suatu produk sebagai penunjang pembelajaran peserta didik Sekolah Menengah Pertama. Pengembangan produk dilakukan di program studi 
pendidikan Fisika. Universitas negeri Jakarta dan pengujian produk dilaksanakan di sekolah menengah pertama.

\section{HASIL DAN PEMBAHASAN}

\section{Produk yang Dihasilkan}

\section{a. Buku IPA yang dihasilkan}

Buku Ilmu Pengetahuan Alam (IPA) yang dihasilkan digunakan sebagai penunjang pembelajaran di Sekolah Menengah Pertama (SMP). Buku IPA ini, di dalamnya memiliki penjelasan yang sama seperti buku-buku penunjang pembelajaran yang lainnya seperti penjelasan tentang pendahuluan, isi Buku, dan penutup. Penjelasan ini merupakan kegiatan peserta didik dalam pembelajaran untuk mencapai kemampuan berpikir ilmiah atau saintifik sehingga, peserta didik dapat meningkatkan kemampuan memecahkan masalah, berpikir ilmiah, menganalisis, mengklasifikasi, dan menyimpulkan keputusan.

1) Pendahuluan

Pada langkah ini akan disajikan langkah-langkah yang harus dilakukan oleh peserta didik sebelum proses pembelajaran berlangsung. Dilangkah ini, akan disajikan kompetensi dasar setiap materi, peta konsep setiap materi, dan tujuan pembelajaran yang akan dicapai setiap materinya, yang mana harus dikuasai oleh peserta didik. Dari tahap ini diharapkan peserta didik mempunyai kemampuan awal sebelum melaksanakan pembelajaran.

2) Isi Buku

Pada tahap ini akan disajikan penjelasan isi pembelajaran setiap materi yang didalamnya terdapat materi yang menggunakan aplikasi Augmented Reality terkait penjelasan gambar dari setiap materinya, kegiatan-kegiatan pembelajaran setiap materinya yang mana menggunakan aplikasi Augmented Reality, contoh dan pembahasan soal setiap materinya, dan latihan soal setiap materinya. Yang berguna untuk membantu menambah pemahaman peserta didik dalam pembelajaran sehingga, dapat meningkatkan konsep peserta didik dalam membangun kompetensi dasar yang akan dicapai.

3) Penutup

Pada tahap ini akan disajikan kesimpulan dan evaluasi terhadap peserta didik disetiap materinya. Kesimpulan yang disajikan sesuai dengan kompetensi dasar dan materi dari setiap materinya. Dan diarahkan untuk menjawab evalusi sebagai penilaian peserta didik dalam ranah kognitif untuk mendapatkan konsep-konsep IPA yang akan dikuasai terdiri dari (Biologi, Fisika, Kimia), merumuskan konsep dalam persamaan matematika dalam mencapai kemampuan ilmiah atau saintifik.

\section{b. Aplikasi Augmented Reality yang Dihasilkan}

Pada Buku IPA yang dihasilkan terdapat beberapa gambar yang akan dijadikan marker atau penanda. Selanjutnya, marker akan terintegrasi dengan informasi Augmented Reality yang ditampilkan berupa animasi tiga Dimensi atau video. Informasi ini dapat ditampilkan dengan bantuan aplikasi yang terinstal di smartphone android.

Cara penggunaan media ini adalah dengan mengarahkan kamera smartphone android yang telah terintegrasi oleh aplikasi Augmented Reality ke marker yang terdapat dalam Buku IPA Augmented Reality. Selanjutnya, kamera akan menampilkan informasi virtual berupa tiga Dimensi atau video singkat tentang percobaan. kamera digunakan secara offline, sehingga tidak memerlukan jaringan internet. Resolusi kamera diabaikan pada proses ini, yang terpenting jenis android yang digunakan pada smartphone memenuhi syarat minimum.

Lama waktu yang digunakan untuk menampilkan Augmented Reality bergantung pada rating dan ukuran marker, semakin baik rating dan besar ukkuran markernya semakin cepat ditampilkan di kamera [17]. Rating ini didapat dari Vuforia sdk dengan nilai rating tertinggi sebesar lima. Jarak jangkauan kamera terhadap marker dapat diukur saat proses desain menggunakan unity 3D. begitu 
pula dengan ukuran Augmented Reality yang ditampilkan, dapat diatur pula saat proses desain menggunakan unity 3D.

\section{c. Pengelompokkan Buku IPA berdasarkan keterampilan Saintifik}

TABEL 1. Keterampilan Saintifik

\begin{tabular}{|c|c|c|c|}
\hline No & Jenis keterampilan & Contoh bagian Buku IPA & Keterangan \\
\hline & & & $\begin{array}{l}\text { Pada bagian pertanyaan. } \\
\text { Awal : } \\
\text { Peserta didik diminta untuk } \\
\text { mampu memecahkan persoalan } \\
\text { yang ada dengan tepat. }\end{array}$ \\
\hline 1 & Mengamati & Scan ar & $\begin{array}{l}\text { Pada bagian penerapan. } \\
\text { Konsep : } \\
\text { Peserta didik diminta untuk dapat } \\
\text { menelaah video pembelajaran } \\
\text { dengan tepat sehingga dapat } \\
\text { menjadi petunjuk pelaksanaan } \\
\text { pembelajaran dengan baik. }\end{array}$ \\
\hline \multirow{2}{*}{2} & \multirow{2}{*}{ Menanya } & & $\begin{array}{l}\text { Pada bagian pertanyaan. } \\
\text { Awal: } \\
\text { Peserta didik diminta untuk } \\
\text { mampu mengajukan pertanyaan } \\
\text { mengenai persoalan yang ada } \\
\text { dengan tepat. }\end{array}$ \\
\hline & & Scan ar & $\begin{array}{l}\text { Pada bagian penerapan. } \\
\text { Konsep : } \\
\text { Peserta didik diminta untuk dapat } \\
\text { membentuk pikiran kritis dalam } \\
\text { mengajukan pertanyaan mengenai } \\
\text { video pembelajaran yang ada. }\end{array}$ \\
\hline 3 & Menalar & & $\begin{array}{l}\text { Pada bagian pertanyaan. } \\
\text { Awal : }\end{array}$ \\
\hline
\end{tabular}




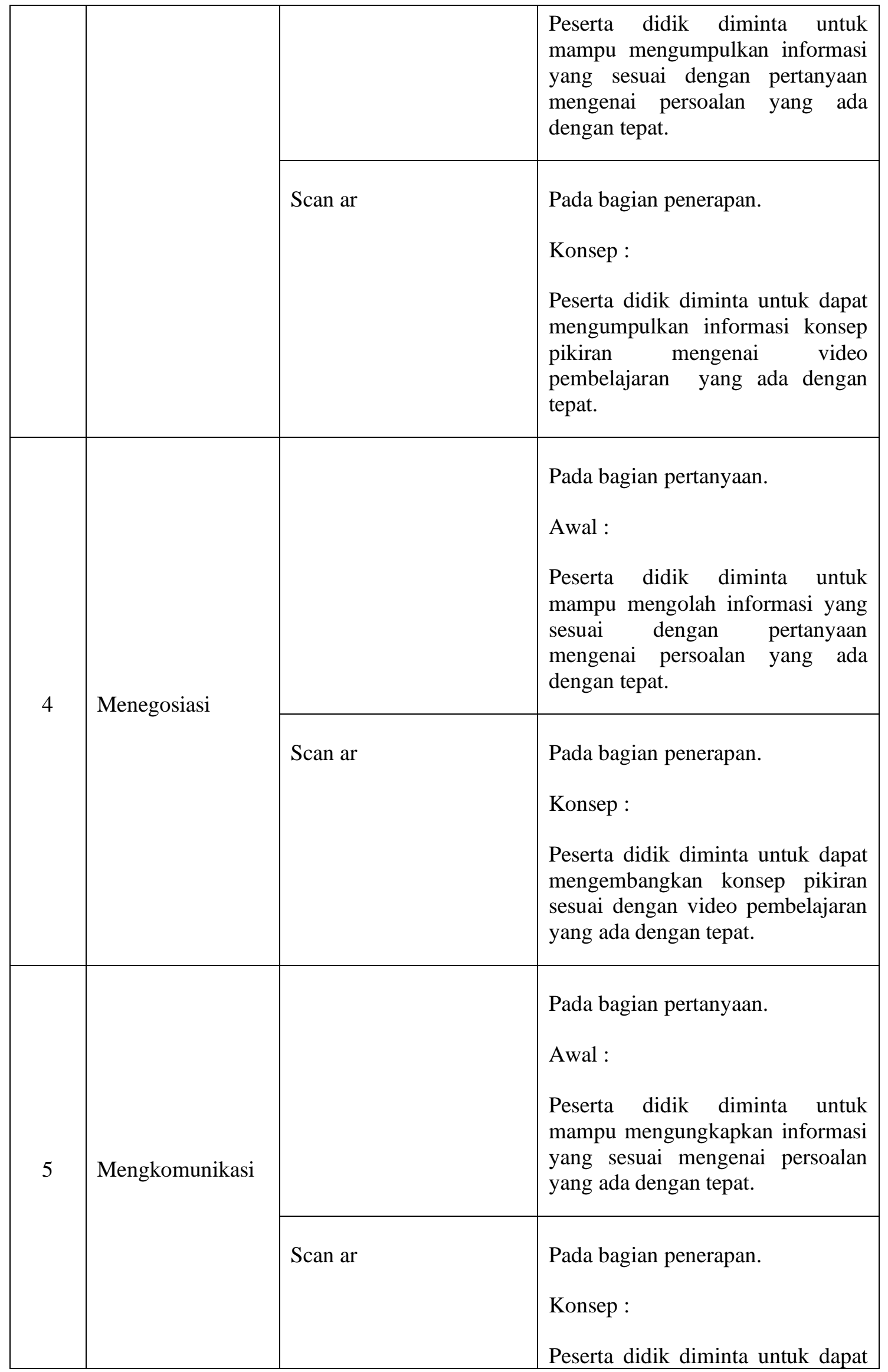




\begin{tabular}{|l|l|l|}
\hline & $\begin{array}{l}\text { menerapkan video pembelajaran } \\
\text { dengan tepat sehingga dapat } \\
\text { menjadi petunjuk pelaksanaan } \\
\text { pembelajaran dengan baik. }\end{array}$ \\
\hline
\end{tabular}

Berikut tahapan yang dilakukan untuk membuat Buku IPA dilengkapi AR tersebut diantaranya :

\section{a. Buku}

Tahap ini dilakukan untuk mulai menyusun kerangka dasar dari Buku IPA yang dikembangkan menjadi Buku IPA dilengkapi AR.

Berikut desain template Buku IPA yang dirancang dengan menggunakan canva:

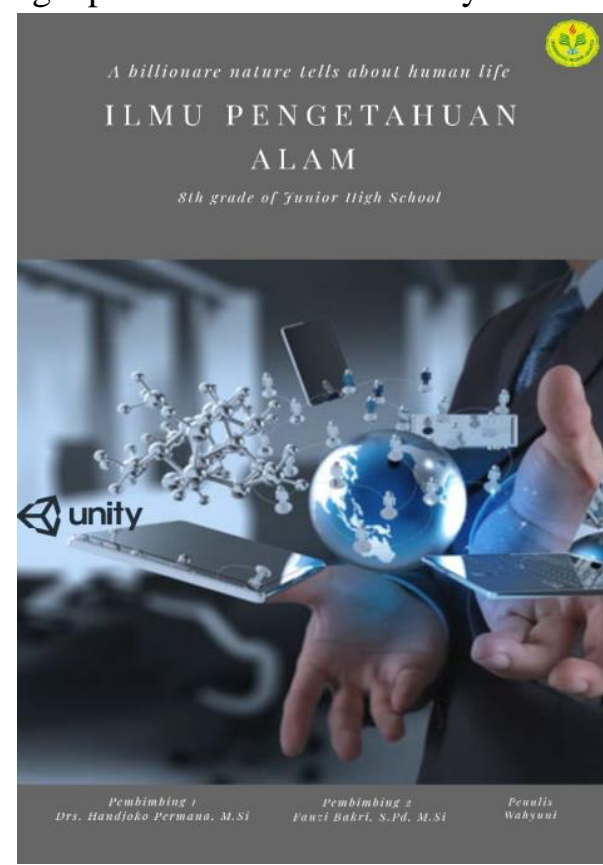

b. Marker

Marker atau penanda digunaan sebagai lokasi titik kemunculan dari objek AR.

c. Augmented Reality (AR)

Software yang digunakan untuk membuat aplikasi AR adalah Unity seri 5.6.2f1 dan Vufotia AR Extension for Unity.

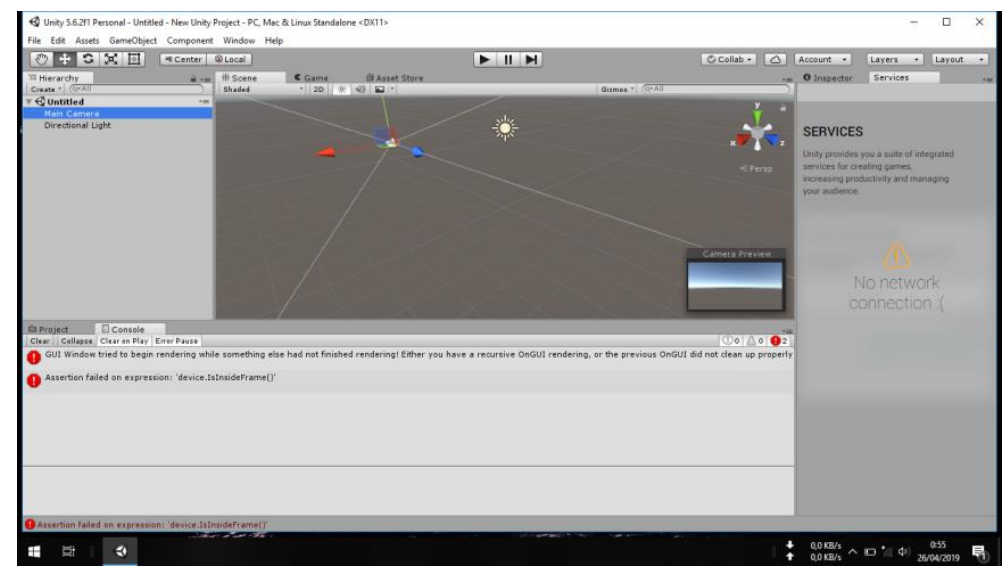




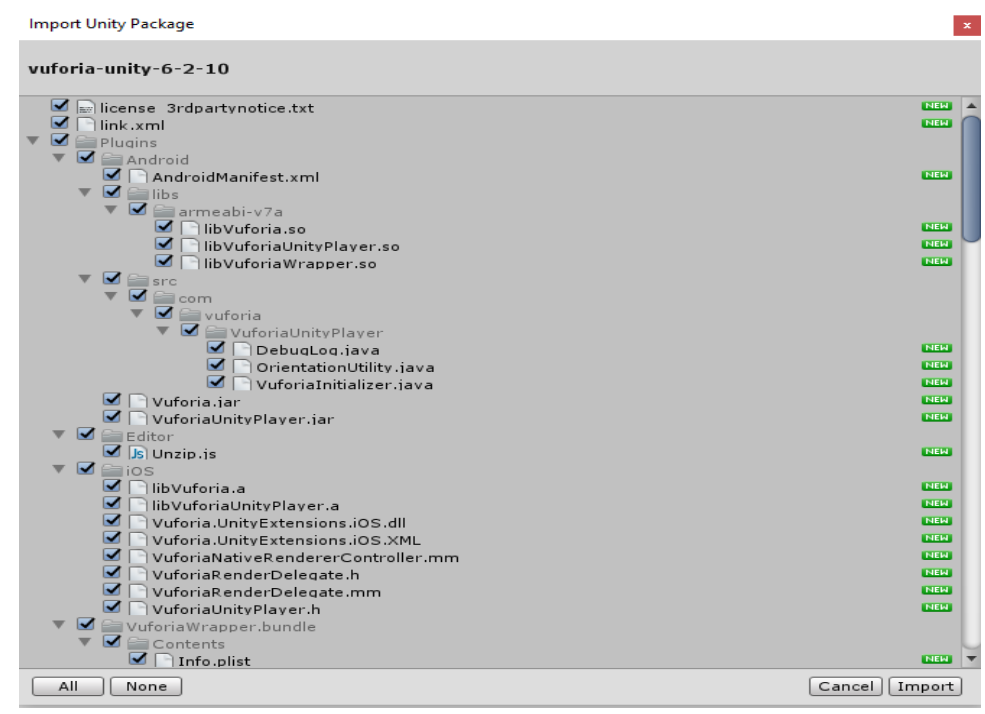

\section{d. Blender}

Blender merupakan alat aplikasi yang digunakan untuk membuat objek diam menjadi bergerak berupa animasi grafis.

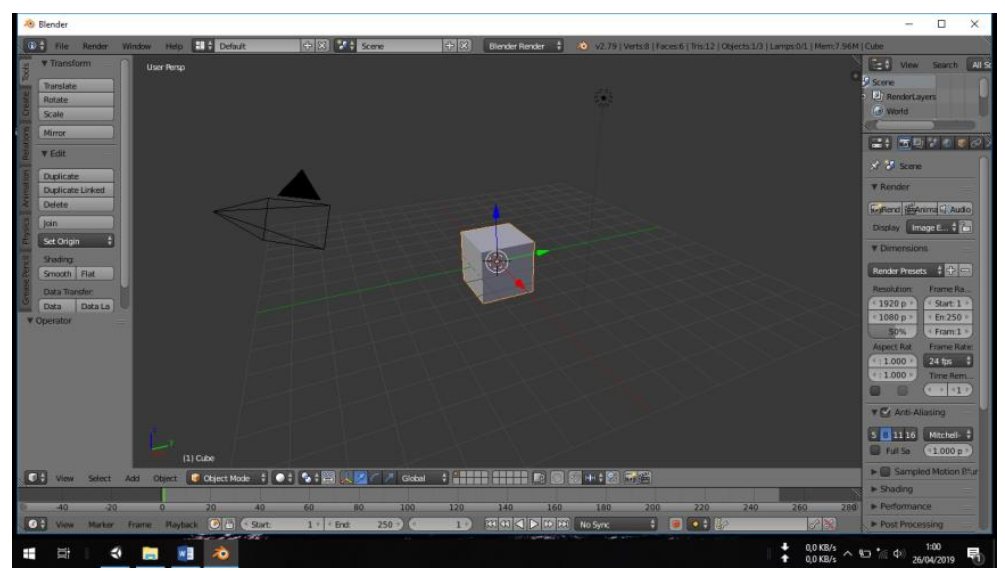

e. Pembuatan interface aplikasi Augmented Reality (AR)

Interface dibuat menggunakan aplikasi Canva. Berikut interface yang telah dibuat untuk aplikasi AR yang digunakan Buku IPA ini adalah sebagai berikut :

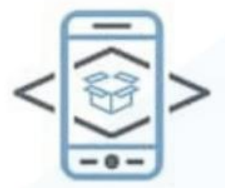



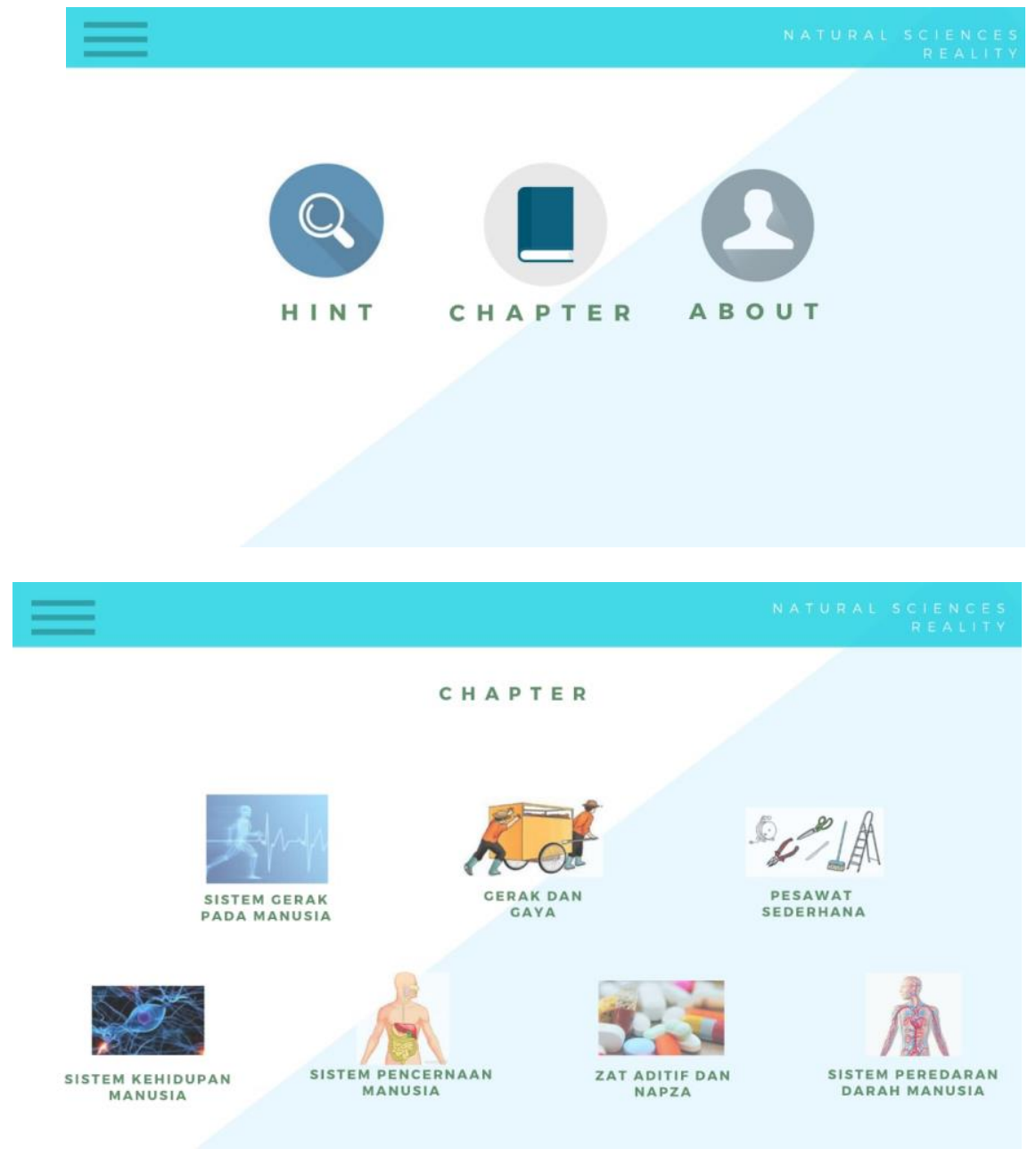

\section{Hasil Uji Validitas}

1Setelah produk selesai dicetak, selanjutnya dilakukan uji validitas untuk mengukur kelayakan produk yang telah dikembangkan demi memenuhi standar media pembelajaran yang baik. Uji validitas dilakukan oleh dua orang ahli, yaitu ahli materi dan ahli media. Kedua ahli tersebut mengukur setiap aspek dari produk yang telah dikembangkan. Berikut ini merupakan TABEL berisi aspek penilaian dari setiap validator.

TABEL 2. TABEL aspek validasi ahli materi dan ahli desain media

\begin{tabular}{|c|c|c|c|c|}
\hline \multirow{2}{*}{ No } & \multicolumn{2}{|c|}{ Ahli Materi } & \multicolumn{2}{|c|}{ Ahli 4Media } \\
\hline & Aspek Penilaian & Nilai (\%) & Aspek Penilaian & Nilai (\%) \\
\hline 1 & Pendahuluan & & Komposisi dan Spasi & \\
\hline 2 & Isi & & Warna dan Tulisan & \\
\hline 3 & Penyajian & & Penggunaan & \\
\hline 4 & Bahasa & & Minimalisasi Desain & \\
\hline
\end{tabular}


Dari hasil uji validasi oleh kedua ahli, maka nilai keseluruhan yang diperoleh berdasarkan persamaan (1) pada uji Skala Likert adalah sebagai berikut.

TABEL 3. TABEL skor akhir uji validitas dari masing-masing ahli

\begin{tabular}{ccc}
\hline No & Ahli Validasi & Skor Akhir $(\%)$ \\
\hline 1 & Materi & - \\
2 & Desain Media & - \\
\hline
\end{tabular}

Dari TABEL 3 dapat dideskripsikan bahwa menurut ahli materi - $\%$ materi pada Buku IPA Augmented Reality telah layak untuk dijadikan penunjang bahan ajar dalam pembelajaran. Sementara itu, skor akhir dari ahli media sebesar -\% Buku IPA Augmented Reality telah sesuai standar media sehingga layak untuk dijadikan variasi media belajar di sekolah. Setelah uji validasi dilaksanakan selanjutnya produk telah siap untuk diujicobakan di Sekolah Menengah Pertama.

\section{SIMPULAN}

Berdasarkan skor akhir uji validitas, Buku IPA Augmented Reality ini layak dijadikan media pembelajaran di Sekolah Menengah Pertama, membantu guru untuk mengembangkan kegiatan belajar mengajar, serta menambah variasi media pembelajaran di sekolah. Namun begitu, isi materi pada Buku IPA Augmented Reality ini dapat dikembangkan lagi dengan video 3 Dimensi yang bervariasi dan terkini.

\section{REFERENSI}

[1] Bintari, R.W., Sudiana, N., \& Putrayasa, I. B. (2014). Pembelajaran Bahasa Indonesia Berdasarkan Pendekatan Saintifik (Problem Based Learning) sesuai Kurikulum 2013 di Kelas VII SMP Negeri 2 Amlapura. E-Journal program Pascasarjana Universitas Pendidikan Ganesha.

[2] Majid, A. (2017). Perencanaan Pembelajaran. Bandung: PT. Remaja Rosda Karya Offset.

[3] Amir, Isnawati. (2017). Pengembangan Buku Ajar Dan Augmented Reality (AR) Pada Konsep Sistem Pencernaan Di Sekolah Menengah Atas. S2 thesis : Program Pascasarjana Universitas Negeri Makassar.

[4] Majid, A. (2017). Perencanaan Pembelajaran. Bandung: PT. Remaja Rosda Karya Offset.

[5] Dunser, A. C. (2012). An Interactive Augmented Reality Coloring Book. IEEE Symposium on 3D User Interfaces (3DUI), 2012 pp. 7-10

[6] Lee, K. (2012). Augmented Reality In Education And Training. Tech Trends Link. Res. Pr. Improve Learn., vol. 56, no.2.

[7] Bakri, F., Marsal, O., \& Muliyati, D. (2019). Textbooks Equipped with Augmented Reality Technology for Physics Topic in High-School. Jurnal Penelitian dan Pengembangan Pendidikan Fisika, 5(2), 113-122.

[8] Bakri, F., Ambarwulan, D., \& Muliyati, D. (2018). Pengembangan Buku Pembelajaran Yang Dilengkapi Augmented Reality Pada Pokok Bahasan Gelombang Bunyi Dan Optik. Gravity: Jurnal Ilmiah Penelitian dan Pembelajaran Fisika, 4(2).

[9] Bakri, F., Sumardani, D., \& Muliyati, D. (2019, December). The 3D simulation of Lorentz Force based on augmented reality technology. In Journal of Physics: Conference Series (Vol. 1402, No. 6, p. 066038). IOP Publishing.

[10] Bakri, F., Sumardani, D., \& Muliyati, D. (2019, December). The augmented reality application for simulating electromotive force concept. In Journal of Physics: Conference Series (Vol. 1402, No. 6, p. 066039). IOP Publishing. 
[11] Bakri, F., Sumardani, D., \& Muliyati, D. (2019, November). Integrating augmented reality into worksheets: Unveil learning to support higher-order thinking skills. In AIP Conference Proceedings (Vol. 2169, No. 1, p. 020012). AIP Publishing.

[12] Bakri, F., Ervina, E., \& Muliyati, D. (2019, November). Practice the higher-order thinking skills in optic topic through physics worksheet equipped with augmented reality. In AIP Conference Proceedings (Vol. 2169, No. 1, p. 020006). AIP Publishing.

[13] Bakri, F., Pratiwi, S., \& Muliyati, D. (2019, November). Video-enriched worksheet based on augmented reality technology: The heat experiment is easier. In AIP Conference Proceedings (Vol. 2169, No. 1, p. 020010). AIP Publishing.

[14] Muliyati, D., Viridi, S., Fitriani, E., Siswoyo, \& Ambarwulan, D. (2019, November). Explain the physics concepts with flood phenomena using augmented reality technology. In AIP Conference Proceedings (Vol. 2169, No. 1, p. 020009). AIP Publishing.

[15] Yusiran, Y., \& Siswanto, S. (2016). Implementasi Metode Saintifik Menggunakan Setting Argumentasi pada Mata Kuliah Mekanika untuk Meningkatkan Kemampuan Kognitif Mahasiswa Calon Guru Fisika. Jurnal Penelitian \& Pengembangan Pendidikan Fisika, 2(1), 15 $-22$.

[16] Ilhami Novili, W., Utari, S., \& Saepuzaman, D. (2016). Penerapan Scientific Approach untuk Meningkatkan Literasi Saintifik dalam Domain Kompetensi Siswa SMP pada Topik Kalor. Jurnal Penelitian \& Pengembangan Pendidikan Fisika, 2(1), 51 - 56.

[17] Ambarwulan, D., \& Muliyati, D. (2016). The Design of Augmented Reality Application as Learning Media Marker-Based for Android Smartphone. Jurnal Penelitian \& Pengembangan Pendidikan Fisika, 2(1), 73 - 80. 